\title{
Investigating the significance of disaster information management
}

\begin{tabular}{|c|c|}
\hline \multicolumn{2}{|c|}{$\begin{array}{l}\text { Author: } \\
\text { Mukundi Mutasa }{ }^{1,2}\end{array}$} \\
\hline \multicolumn{2}{|c|}{$\begin{array}{l}\text { Affiliations: } \\
{ }^{1} \text { Institute of Development } \\
\text { Studies, National University } \\
\text { of Science and Technology } \\
\text { (IDS-NUST), Zimbabwe }\end{array}$} \\
\hline $\begin{array}{l}{ }^{2} \text { Environment } \\
\text { Zimbabwe }\end{array}$ & Africa, \\
\hline \multicolumn{2}{|c|}{$\begin{array}{l}\text { Correspondence to: } \\
\text { Mukundi Mutasa }\end{array}$} \\
\hline \multicolumn{2}{|c|}{$\begin{array}{l}\text { Email: } \\
\text { mmutasa@gmail.com }\end{array}$} \\
\hline \multicolumn{2}{|c|}{$\begin{array}{l}\text { Postal address: } \\
\text { PO Box A1887, Avondale, } \\
\text { Harare, Zimbabwe }\end{array}$} \\
\hline \multicolumn{2}{|c|}{$\begin{array}{l}\text { Dates: } \\
\text { Received: } 09 \text { July } 2012 \\
\text { Accepted: } 07 \text { Jan. } 2013 \\
\text { Published: } 14 \text { Feb. } 2013\end{array}$} \\
\hline \multicolumn{2}{|c|}{$\begin{array}{l}\text { How to cite this article: } \\
\text { Mutasa, M., 2013, } \\
\text { 'Investigating the significance } \\
\text { of disaster information } \\
\text { management', Jàmbá: } \\
\text { Journal of Disaster Risk } \\
\text { Studies 5(2), Art. \#73, } 6 \\
\text { pages. http://dx.doi.org/ } \\
\text { 10.4102/jamba.v5i2.73 }\end{array}$} \\
\hline \multicolumn{2}{|c|}{$\begin{array}{l}\text { Note: } \\
\text { 1st Biennial Conference, } \\
\text { Southern African Society for } \\
\text { Disaster Reduction (SASDiR), } \\
09 \text { to } 11 \text { October 2012, } \\
\text { Potchefstroom, South Africa }\end{array}$} \\
\hline \multicolumn{2}{|c|}{$\begin{array}{l}\text { Copyright: } \\
\text { (C) 2013. The Authors } \\
\text { Licensee: AOSIS } \\
\text { OpenJournals. This w } \\
\text { is licensed under the } \\
\text { Creative Commons } \\
\text { Attribution License. }\end{array}$} \\
\hline \multicolumn{2}{|l|}{ Read online: } \\
\hline 口ifing & $\begin{array}{l}\text { Scan this QR } \\
\text { code with your } \\
\text { smart phone or } \\
\text { mobile device } \\
\text { to read online. }\end{array}$ \\
\hline
\end{tabular}

Disaster information informs disaster risk management interventions. However, it is the systematic management of this key resource that has not yet been fully embraced. In some cases, information is still haphazardly collected, analysed, managed and disseminated. This paper, utilising mainly secondary literature sources, explores the importance of disaster information and its systematic management in disaster risk management programming. It presents challenges associated with information management in disaster situations and critiques the trend whereby the collection, management and dissemination of information are usually limited to disaster situations. This only serves to further marginalise post-disaster recovery processes, which are integral with regard to generating knowledge essential for the formulation of future disaster mitigation strategies. The paper concludes by arguing for the integration of disaster information management into current disaster risk management curriculum.

\section{Introduction}

Information is a key resource informing all human activities. Its 'acquisition and distribution ... is essential to human empowerment and ... if people have better access to this basic resource this would greatly benefit their standard of living' (Hamelink 2002:5). Without this resource, there is a high probability that humankind will repeat past mistakes. There are grave consequences of information famine, especially for communities that are prone to disasters. As such, experiences with past disasters should be well documented, managed and communicated so as to help with regard to managing future risk. This paper, inspired by research for content to develop a postgraduate diploma course - Disaster Information Management - at the National University of Science and Technology (NUST) in Zimbabwe, sought to explore the importance of information management and how this relates to disaster risk management (DRM).

\section{Problem statement}

While the importance of information in any sector cannot be overemphasised, it is its management that organisations have not yet fully embraced. Currion (2003:2) argues that information management is not high on the list of priorities for most humanitarian organizations', whilst the wide spectrum of information collectors and users in humanitarian situations makes information management an uphill task. Currion makes reference to information 'drought' and information 'flood' as some of the challenges facing humanitarian organisations and practitioners. It is, therefore, vital for humanitarian organisations to put in place systems that are favourable in order for effective disaster information management to thrive at all levels of the disaster and risk management cycle.

\section{Research Objectives}

The objectives of this research were to:

- explore the importance of information management in disaster risk management

- identify the challenges associated with disaster information management

- identify the most appropriate ways of improving the management of disaster information.

\section{Research Methodology}

The paper utilised a qualitative research method and reviewed secondary literature on disaster information management and the importance of appropriately managing the said information, as it is integral in managing disaster risk. A narrative review was chosen mainly because there was limited time to carry out field research prior to developing and delivering the course. This approach was crucial as it provided lessons from other areas that were documented in secondary literature. Narrative reviews are not without challenges though. As Bryman (2008:105) argues, 
there are times when such documented experiences 'are sometimes misleadingly represented in publications.' It is, therefore, important that researchers are privy to this challenge, and that they exercise extreme caution when basing their analyses solely on secondary literature.

\section{Defining disaster information}

Information relating to disasters is particularly important as it informs DRM activities. In this paper, the term information refers to processed data. The processing of data is meant to put it 'into a form that is meaningful to the recipient and is of real or perceived value in current or prospective actions or decisions' (Davis \& Olson, quoted in Knight \& Silk 1990:22). Hanson and Kararach (2011:2) argue that for data to become information, it 'must be processed and structured into a meaningful, composite model', whilst Powell (2003:42) gives reference to the value chain 'whereby data can become information, which can then be transformed into knowledge.' In fact, Table 1 can be used to provide this hierarchical representation.

\section{On the other hand, a disaster has been defined as:}

[a] serious disruption of the functioning of a community or a society causing widespread human, material, economic or environmental losses which exceed the ability of the affected community or society to cope using its own resources (United Nations Inter-Agency Secretariat of the International Strategy for Disaster Reduction [UN/ISDR] 2004:17)

Disasters are the outcome of the presence of hazards and people's inability to cope with the hazards that they face. It is important to emphasise here that hazards such as droughts, floods and earthquakes only become disasters when they have killed or injured people, or destroyed their property. As such, according to Timberlake (1988:13), it 'is the relationships between humans and these trigger events [hazards] which determine whether a disaster will occur, and, if so, how big it will be.' Disasters, by their nature, cause serious disruptions to processes towards human development. Wisner et al. (2004:5) argue that disasters act as 'a brake on economic and human development at the household level ... and at the national level', whilst Ehrenreich (2001:22) opines that disasters 'create tears in the tissue of social life.' Meanwhile, DRM can be defined as:

the systematic process of using administrative decisions, organization, operational skills and capacities to implement policies, strategies and coping capacities of the society and communities to lessen the impacts of natural hazards and related environmental and technological disasters. (UN/ISDR 2004:17)

Powell (2003:41) stipulates that information can also be defined according to the purpose that it serves, for example, financial

TABLE 1: Hierarchical presentation and some definitions.

\begin{tabular}{|c|c|}
\hline Stage & Definition \\
\hline 1. Data & Numbers representing an observable object or event (fact) \\
\hline 2. Information & $\begin{array}{l}\text { Human significance associated with an observable object or } \\
\text { event, i.e. processed data }\end{array}$ \\
\hline 3. Knowledge & Theoretical or practical understanding of a subject \\
\hline 4. Wisdom & Experience and knowledge applied with judgement \\
\hline
\end{tabular}

information, monitoring information, transport information and management information. Using this definition, it can, therefore, be argued that disaster information relates to the information function of disasters. Such information can include anything relating to the relationship between disasters, people and their environment, for example:

- the vulnerability of the communities to the various hazards

- the history of hazards in that locality

- the risk of disasters occurring and recurring

- predisaster predictions and warnings (early warning)

- the impact in the event that a hazard escalates into a disaster

- the response carried out and/or is necessary

- the actions necessary for reduction of future impacts (adaptation strategies, risk reduction, and resilience building), et cetera.

Important information relating to disasters and emergencies includes, inter alia, the location of the disaster; the number of people affected preferably disaggregated according to factors such as age and sex; the extent of the damage; the resources that are available to support disaster response efforts (International Federation of Red Cross and Red Crescent Societies [IFRC] 2000:7); and the resources needed to facilitate a smooth response to such disasters. Early predictions and warnings are another information resource integral to the facilitation of effective DRM. These help practitioners 'to monitor natural hazards, plan response activities, identify affected populations and their needs, assess the flexibility of existing instruments or the functioning of markets or facilitate targeting of beneficiaries' (Vakis 2006:8). It is also argued that the communities that have 'better access to information', in addition to other resources such as cash, household assets, access and rights to production means, and social protection networks, 'are less vulnerable to hazards, and may be in a position to avoid disaster' (Wisner et al. 2004:93). The availability and easy accessibility of that information are essential as they help with the selection and monitoring of appropriate interventions, and encourage 'accountability among the agencies, donors, and governments involved' in disaster response activities (McDonnell et al. 2007:316).

Disaster information is, therefore, a key resource that requires proper management so that it can easily be accessed by those who need it, at the right time and in the right format. It is essential that this information be correct so that it can inform the development of appropriate DRM strategies. Ehrenreich (2001:53) emphasises the importance of communicating such information, arguing that holding on to essential information in disaster situations might increase insecurity in the affected areas and that 'uncertainty increases victims' level of stress.' This is supported by Hamelink (2002) who opines that the communication of information, which is 'at the heart of social development' (p. 9) is often marginalised, thus further contributing to 'unequal access to information' (p. 5). However, it is important to emphasise that communicating 'incorrect information produces confusion, can interfere with appropriate responses, and can lead to tensions among victims or between victims and relief workers' (Ehrenreich 
2001:53). As such, Principle IV of Psychosocial Intervention following Disasters, as quoted by Ehrenreich (2001:53) recommends that those with the information should:

provide victims with accurate and full information, as quickly as possible, using both individual, direct forms of communication and general public announcements... [They should] combat rumor mongering ... [and] have a single source of information which victims can rely upon.

Relating to development organisations, Powell (2003) argues that they need to be privy to what is happening, constantly keeping up to date with the changes going on, and providing information to those who need it. Experiences with floods in Lusaka, Zambia, in 1989, for example, showed that the local populace needed to be involved in national development and DRM activities, and that such activities should 'provide public information and education programmes' (Mulwanda 1993:69). Powell (2003) further argues that without such provision of the information to the people needing it, development organisations cannot safely claim that they are making a difference as development will not be taking place. Despite the understanding that information availability and accessibility are integral to DRM, it is regrettable that the disaster-affected communities are usually left out of the information provision equation. The following quotation from IFRC (2005:12) probably best sums up this unfortunate finding:

Information is also a vital form of aid in itself. People need information as much as water, food, medicine or shelter. Information can save lives, livelihoods and resources. It may be the only form of disaster preparedness that the most vulnerable can afford. And yet it is very much neglected. Aid organizations have focused on gathering information for their own needs and not enough on exchanging information with the people they aim to support. [Emphasis added.]

\section{What is information management?}

Information management, as a concept, was borrowed from a variety of disciplines. Powell (2003:47) asserts that the field's theory and practice grew 'from a number of roots [that] include differing cultural and philosophical approaches, as well as varied professional backgrounds.' These disciplines include 'business studies, management and organisational theory, librarianship, data processing and computer studies' (Powell 2003:47). The United Nations Office for the Coordination of Humanitarian Affairs (OCHA) (2006:2) quotes the Association for Information Management (Aslib) as defining information management in a more elaborate way stressing that it involves the various stages of information processing from production to storage and retrieval to dissemination towards the better working of an organization.' It is further elaborated that this information can be collected from internal and/or external sources and can come in varying formats (OCHA 2006:2).

The concept of information management makes it integral for the manager and user of that information to be able to analyse it based on how it was collected, processed, analysed and disseminated. These comprise the four stages of what

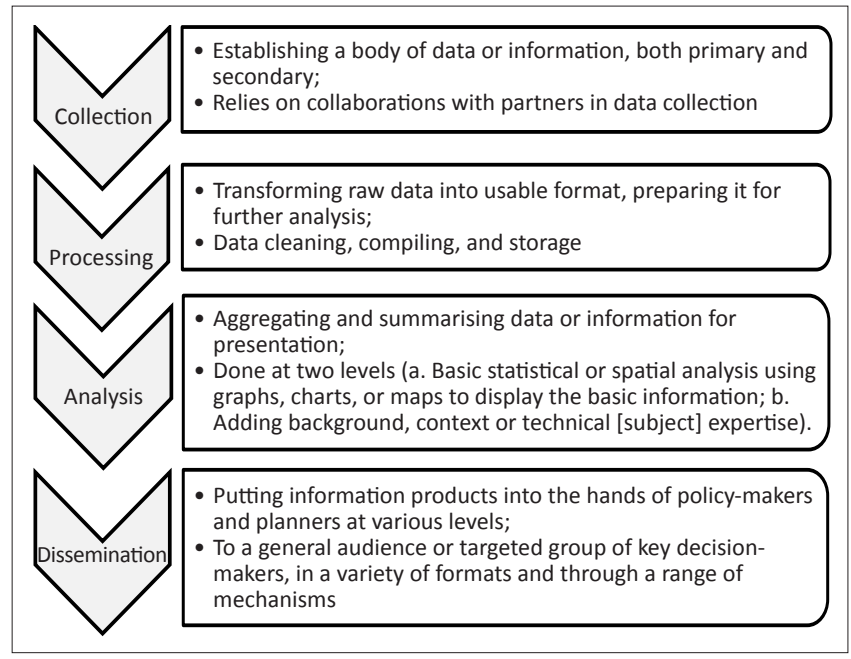

Source: Adapted from OCHA (2006:2)

FIGURE 1: Information Management Chain.

is termed the Information Management Chain as shown in Figure 1 (adapted from OCHA 2006:2). All four stages are very important in ensuring that information is managed properly, and that it appropriately informs the activities that an organisation engages in. In order for the information to benefit the organisation, it is important that it be collected, processed, analysed and disseminated following appropriate procedures. There are cases, though, when following such procedures is difficult, and this is particularly the case in a disaster situation. However, in the absence of a proper information management system, it would be even more difficult to smoothly collect, process, analyse and disseminate information so that it could be accessed and used by those who need it. When information is not accessed and used, then collecting and keeping it becomes a pointless exercise.

Powell (2003:45) emphasises the need to understand how that information was constructed, arguing that information becomes more powerful and more effective the more solidly it is based or constructed.' It is important to know who constructed the information and why, what their opinions are, what they are trying to communicate, and that the people who are prone to disasters are not marginalised in constructing and disseminating that information. Well constructed information is important in that:

- it 'makes clear who was involved in collecting it, when and where'

- it 'explains the context of the information and its status (raw data, interpretation, or analysis)'

- it 'seeks to test or to provide alternative meanings'

- '[i]t makes explicit links to other uses of the information'

- its construction 'is transparent and open to questioning'. (Powell 2003:45)

However, the various power dynamics associated with the creation of information cannot be downplayed. These are associated mainly with gender inequality and social exclusion, literacy, income, status in society, and authority barriers. For example, in most patriarchal societies (this includes most communities in Africa), people undervalue information and 
knowledge generated or possessed by women and/or the youth compared to that from men and/or the elderly. As such, inasmuch as women and/or the youth might possess very important information, not much attention may be paid to their contributions. Agrawal (2008:418) asserts that 'numerous indigenous cultures discriminate against women possessing knowledge that members of the culture value', yet 'women may possess particularly rich insights about some aspects of their culture.' This is particularly the case with information on natural resources management, yet women interact with the natural environment as it is their main source of livelihood.

Women are also disadvantaged when it comes to accessing disaster information. This has largely been the cause of higher casualties of women than men in disaster situations, partly because of women's traditional roles that confine them to households (Ehrenreich 2001). This is regardless of the fact that 'women have proved effective in mobilizing the community to respond to disasters, and in disaster preparedness and mitigation' (Women's Environment and Development Organization [WEDO] 2008:11).

\section{Importance of Disaster Information Management}

As already argued in this paper, information management is of particular importance to all organisations, not only DRM-oriented organisations. It improves access to and use of information, which is a key resource in DRM activities. In the absence of a proper information management system, it would be difficult not only to access and use the information, but to even know what information will be available, and what purpose it can serve for that individual or organisation.

Figure 2, taken from Powell (2003:48), illustrates that good information management should aim at efficiency, effectiveness, creativity and empowerment as elaborated below:

- Good information management is aimed at making the organisation more efficient. According to Stoner, Freeman and Gilbert (1995:9), efficiency provides an organisation

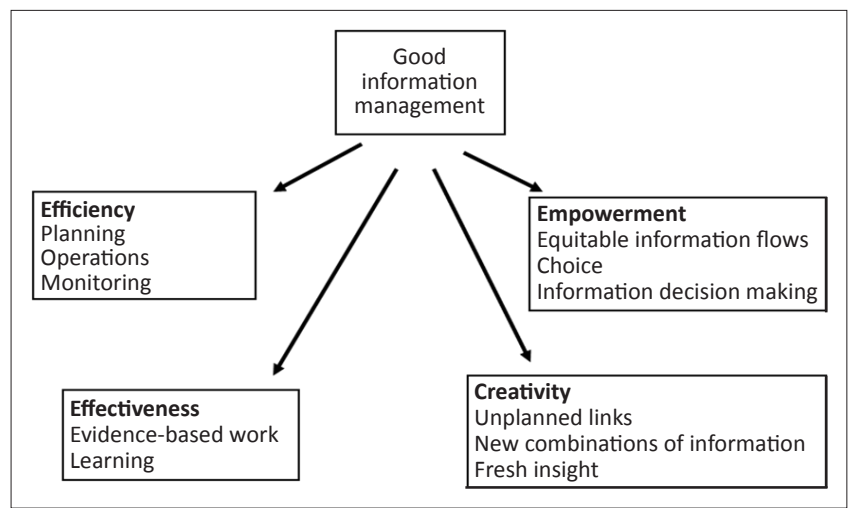

Source: Powell (2003:48)

FIGURE 2: The core aims of information management. with the 'ability to minimize the use of resources in achieving organizational objectives [thereby] doing things right'. For this to be possible, the information must be:

of appropriate quality, collected once, and distributed appropriately, rather than being re-collected by every department. Information will be available to those who need it, not hidden away in poorly catalogued archives, or simply lost... People will have easy access to what they need to know, without wasting too much time wading through information that they cannot use. (Powell 2003:48)

- Information management is aimed at making the organisation more effective, meaning that good management of available information resources gives organisations 'the ability to determine appropriate objectives: "doing the right thing"' (Stoner et al. 1995:9). Information should aid the organisation in identifying its goals and in becoming 'aware of the information needs of those with whom it works' (Powell 2003:48). The various players implementing DRM activities have a wide array of information needs, and it is essential that they are privy to the information needs of their partners so that they can effectively implement the activities and aim to achieve a common goal. For DRM-oriented organisations, this goal should be to reduce the possibility of disasters occurring in their areas of jurisdiction. It is important that whilst in the process of implementing activities aimed at managing risk for a particular disaster, these organisations do not create more vulnerability in those communities to other disasters.

- Through appropriate information management practices, organisations become more creative. Creativity involves developing 'new ideas, practices, and new relationships' (Powell 2003:49). The organisation's information resources are integral in informing these new developments. Effective DRM can only be achieved through innovative thinking and actions. As such, disaster information management contributes to such a goal where organisations develop new ways of managing disaster risk, even in communities where there is little or no likelihood of a disaster occurring in the short term.

- In order for DRM-oriented organisations to thrive, they should tap into the strengths (talents) of their staff and partners. As such, information management should aim at improving the capacity of staff, organisational partners, and the at-risk communities. Through good information management, the 'people will be better informed about what is happening, which will increase their capacity to make better decisions' (Powell 2003:49).

It is, therefore, essential for DRM-oriented organisations to put in place effective information management systems. According to IFRC (2000:5), an effective information management system:

provides selective information relevant to the specific decision maker's need. It also clarifies particular problems and available options, and helps the user to make reasonable choices about what actions to take. It does not drown the decision maker in a sea of information, but rather, adds value and coherence to his/ her activities.

Although this is the ideal situation, it is, however, noted that 'establishing and maintaining an information system 
is difficult in any context; after a disaster it is even more difficult' (McDonnell et al. 2007:316). As such, it is fundamental to ensure that such a system is in place even before a disaster occurs. This is particularly important as the system will then assist in the management of disaster risk in such communities.

\section{Challenges faced in the management of disaster information}

Disaster information management faces a number of challenges. Firstly, the post-disaster environment is difficult to work in, and information collection is usually of lesser value at that point than is relief aid. Understandably, the affected communities are usually too traumatised to provide information when their primary concern is survival. In any environment, a properly-constituted information system is necessary for the collection of reliable data regarding any condition. McDonnell et al. (2007:316) acknowledge that establishing an information management system after a disaster is very difficult, which makes the whole process of its management even more of a challenge.

The other challenge relates to the construction of the information, as pointed out earlier. Some information is valued more than other information, depending on who was involved in its construction, their gender, level of literacy, status in society, et cetera. Indigenous knowledge also appears to be marginalised as compared to scientific knowledge (Agrawal 2008; Ocholla 2007). The valuing of some information or knowledge over other sources in itself presents a huge challenge in identifying which information holds any value. Ideally, information should be valued regardless of its provenance, as long as the information manager can be objective enough when analysing and validating said information.

The tendency by management and other staff to resist change in the organisation's information-related functions poses another challenge to the effective management of information in DRM-oriented organisations. People become comfortable with the way they run their day-to-day business and the status quo becomes more acceptable than an overhaul of the system. In addition, there are some managers who exercise an ironfist type of control over information as the information could give them a comparative advantage in exercising their duties, as well as giving the organisation an edge over other organisations that do not have access to such information. Although this is the norm in profit-making enterprises, Powell (2003) argues that in the social development field, which is where DRM fits in, this is deplorable. The main reason for this is that these organisations are supposed to be driven by humanitarian objectives that make them want to cooperate with whoever is willing to assist humanity in achieving resilience to the impacts of disasters. Being driven by the aim to achieve that comparative advantage over others poses a serious challenge to effective information management in DRM-oriented organisations.
Accessing disaster information can also be 'time consuming and laborious' (UN/ISDR 2004:196). The data is not only scattered, but frequently the 'identification of the disaster can be confusing in countries with many disaster events' (UN/ISDR 2004:196). Mozambique, for example, frequently experiences disasters. That continuous experience might render what can be termed a disaster elsewhere, less of a disaster in Mozambique because it is a familiar occurrence. The same can be said about Zimbabwe, where some vernacular terms can be used interchangeably for hazards and disasters. The Shona term nzara, for example, can be used to refer to drought, hunger, food insecurity or famine. It has also been opined that 'the lack of a specific vernacular term for drought [in some societies in Zimbabwe] can have implications on what exactly the people will be implying as there is a difference between drought and famine' (Mutasa 2010:68). The challenge of classifying hazards and disasters makes information collection in humanitarian situations particularly difficult.

Another challenge associated with disaster information management relates to political interference in the collection, analysis and dissemination of information on disasters. Disasters are usually viewed as exposing the respective governments' 'failure in service delivery' providing critics with the platform to question the governments' commitment to protecting their citizens. As such, some governments might deny humanitarian organisations and the media access to the affected communities for fear that their failures will be exposed. This, therefore, makes issues of disaster risk reduction (DRR) and management highly political (UN/ ISDR 2011:78).

Information management also appears to be limited to periods during the disasters only, further alienating the post-disaster recovery period, yet it is a crucial stage as it informs future DRM activities. Turner (1980:240) asserts that the media needs to 'report long-term effects, the speed and extent of recovery, and lessons learned from the disaster' further arguing that 'poor disaster follow-up makes it difficult for anyone to mount disaster prevention measures, and easy for government agencies-especially legislaturesto sidestep their responsibilities for such measures.' For example, not much post-2008 and 2009 cholera epidemic reporting was carried out in the Zimbabwean media, only for the country to be awakened by yet another outbreak of a diarrhoeal disease-typhoid-in mid-2012.

\section{Disaster information management: the recommendations}

Disaster information management requires the implementation of a solid information management system. It is important that such an information management system be introduced and implemented at all levels in DRM-oriented organisations and their partners, and at all stages of the disaster management cycle. In addition, it is essential that information be collected, processed, analysed and disseminated appropriately before, 
during and after the disasters, and that the post-disaster recovery period be documented and lessons shared. The post-recovery period is particularly important as it is during this period that some vulnerabilities may be created. The integration of disaster information management in the DRM curriculum is important as it will introduce learners to the basics of information management in disaster situations, and during the post-disaster recovery period.

Currion (2003) suggests that investment in staff capacity to better manage humanitarian information is vital to ensuring effective humanitarian information management. This is particularly so considering that information management is a new discipline, especially in humanitarian organisations, with the capacity of staff constantly needing improvements.

It is also essential that indigenous knowledge and scientific knowledge be married in a triangulation process that offsets each other's weaknesses. Additionally, the barriers to effective collection, processing, analysis and dissemination of information, such as gender inequality and social exclusion, illiteracy, and socio-economic disparities, should be eliminated, as these contribute to a weaker information management system.

\section{Acknowledgments}

The author acknowledges the valuable insights received from friends and colleagues at Environment Africa, NUST and the Southern African Research and Documentation Centre (SARDC). These insights helped in shaping the arguments presented in this paper.

\section{Competing interests}

The author declares that he has no financial or personal relationship(s) which may have inappropriately influenced him in writing this paper.

\section{References}

Agrawal, A., 2008, 'Dismantling the Divide between Indigenous and Scientific Knowledge', Development and Change 26(3), 413-439. http://dx.doi.org/10.1111/ j.1467-7660.1995.tb00560.x

Bryman, A., 2008, Social Research Methods, 3rd edn., Oxford University Press, Oxford.

Currion, P., 2003, 'Surviving "Droughts" and "Floods": Stretching the Metaphor for Humanitarian Information Management', Toward an International System Model - A Public Entity Risk Institute Symposium, viewed 29 August 2012, from www. riskinstitute.org/peri/images/file/DroughtsandFloodsPERISymposiumPaper.pdf
Ehreinreich, J.H., 2001, Coping with Disasters: a guidebook to psychosocial intervention, State University of New York, New York.

Hamelink, C.J., 2002, 'Social Development, Information and Knowledge: whatever happened to communication?', Development 45(4), 5-9. http://dx.doi.org/10.1057/ palgrave.development.1110397

Hanson, K.T. \& Kararach, G., 2011, 'The Challenges of Knowledge Harvesting and the Promotion of Sustainable Development for the Achievement of the MDGs in Africa', ACBF Occasional Paper No. 12, The African Capacity Building Foundation, Harare.

IFRC (International Federation of Red Cross and Red Crescent Societies), 2000, Disaster Programme Information and Reporting. Disaster Preparedness Training Programme. Participant resource and learning module, viewed 21 June 2012, from http://www.ifrc.org/Global/Disproin.pdf

IFRC (International Federation of Red Cross and Red Crescent Societies), 2005, World Disasters Report: focus on information in disasters, International Federation of Red Cross and Red Crescent Societies, Geneva.

Knight, A.V. \& Silk, D.J., 1990, Managing Information: information systems for today's general manager, McGraw-Hill, London.

McDonnell, S.M., Perry, H.N., McLaughlin, B., McCurdy, B. \& Parrish, R.G., 2007 'Information for Disasters, Information Disasters, and Disastrous Information', Prehospital and Disaster Medicine 22(4), 315-321.

Mulwanda, M., 1993, 'The need for new approaches to disaster management; the floods in Lusaka, Zambia', Environment and Urbanization 5(2), 67-77. http:// dx.doi.org/10.1177/095624789300500206

Mutasa, M., 2010, 'Zimbabwe's Drought Conundrum: vulnerability and coping in Buhera and Chikomba districts', Master's thesis, Department of International Environment and Development Studies (Noragric), Norwegian University of Environment and Development Studies (Noragric), Norwegian University of
Life Sciences, Aas, Available from http://brage.bibsys.no/umb/bitstream/ Life Sciences, Aas, Available from http://brage.bibsys.no/umb/bitstream/
URN:NBN:no-bibsys_brage_14491/1/Mukundi\%20Mutasa\%20Final\%20Thesis. pdf

OCHA (United Nations Office for the Coordination of Humanitarian Affairs), 2006 'Guidelines for OCHA Field Information Management', viewed 12 May 2012, from http://foodsecuritycluster.org/c/document_library/get_file?p_l_id=224242\&gro upld=120482\&folderld=224578\&name=DLFE-11244.pdf

Ocholla, D., 2007, 'Marginalized Knowledge: An Agenda for Indigenous Knowledge Development and Integration with Other Forms of Knowledge', International Review of Information Ethics 7(9), 1-10.

Powell, M., 2003, Information Management for Development Organisations, 2nd edn., Oxfam GB, Oxford.

Stoner, J.A.F., Freeman, R.E. \& Gilbert, D.R., Jr., 1995, Management, 6th edn., Prentice Hall International, London.

Timberlake, L., 1988, Africa in Crisis: the causes, cures of environmental bankruptcy, 2nd edn., Earthscan Publications, London.

Turner, R.H., 1980, 'The Mass Media and Preparation for Natural Disaster', in NRC (National Research Council), Disasters and the Mass Media: proceedings of the Committee on Disasters and the Mass Media Workshop, February 1979, pp. 281-292, The National Research Council, National Academy of Sciences, Washington, D.C.

UN/ISDR (United Nations Inter-Agency Secretariat of the International Strategy for Disaster Reduction), 2004, Living with Risk: a global review of disaster reduction initiatives. 2004 version - Volume I, United Nations Inter-Agency Secretariat of the International Strategy for Disaster Reduction, Geneva.

UN/ISDR (United Nations Inter-Agency Secretariat of the International Strategy for Disaster Reduction), 2011, Disaster through a Different Lens: behind every effect, there is a cause. A guide for journalists covering disaster risk reduction, United Nations Inter-Agency Secretariat of the International Strategy for Disaster Reduction, Geneva.

Vakis, R., 2006, 'Complementing Natural Disasters Management: the role of socia protection', Social Protection Discussion Paper, No. 0543, viewed 24 June 2012 from http://siteresources.worldbank.org/SOCIALPROTECTION/Resources/SPDiscussion-papers/Social-Risk-Management-DP/0543.pdf

WEDO (Women's Environment and Development Organization), 2008, 'Gender, Climate Change and Human Security: lessons from Bangladesh, Ghana and Senegal', viewed 12 May 2012, from http://www.gdnonline.org/resources/WEDO_Gender CC_Human_Security.pdf

Wisner, B., Blaikie, P., Cannon, T. \& Davis, I., 2004, At Risk: natural hazards, people's vulnerability and disasters, 2 nd edn., Routledge, London. 